\title{
Reproductive Cycle of the Mud Eel, Monopterus Cuchia (Hamilton-Buchanan, 1822) in Bangladesh
}

\section{Chakraborty BK*}

Project Director, Department of Fisheries, Mathshya bhabon, Dhaka, Bangladesh

*Corresponding author: Chakraborty BK, Project Director, Department of Fisheries, Mathshya bhabon, Dhaka, Bangladesh, Tel: 0088-01715-470855; E-mail:

\section{Research Article}

Volume 2 Issue 2

Received Date: February 08, 2018

Published Date: March 02, 2018 bborty@gmail.com

\begin{abstract}
Developmental stages of both male and female gonad and estimation of gonadosomatic index (GSI) of Monopterus cuchia investigated over a period of two years. Four developmental stages such as, spermatogonia, spermatocytes, spermatids and spermatozoa were identified in testis. Three developmental stages of oocytes such as, ogenesis (oogonia, early perinucleolus stage and late early perinucleolus stage), vitellogenesis (early vitellogenic oocytes, advanced vitellogenic oocytes and maturation stage) and atretic stage were differentiated in ovary. Maximum mean gonad weight recorded in May for both female $(62.82 \pm 3.02 \mathrm{~g})$, and male $(8.20 \pm 0.48 \mathrm{~g})$. The testis at early development stages between October and March contained mostly spermatogonia, spermatocytes and spermatids, although a small amount of spermatozoa was also found in March. The mature testis began to develop in the early April and was prominent from May to July. Highest percentage of oogonia in the ovary recorded in the month of November and highest percentage of early and late perinucleolus stage was recorded in the month of January. Matured oocytes occupied the most areas of the ovary which were observed from March to November but it was prominent in May. Oocytes were ovulated in the spawning period and began to absorb from late July.
\end{abstract}

Keywords: Mode of spawning; Gonadal growth; Gonadosomatic index; Monopterus cuchia; Bangladesh

Abbreviations: GSI: gonado Somatic index; OG: OOGONIA; DP: dorsal peritoneum; EPN: Early perinucleolus stage; PGC : primary germ cells

\section{Introduction}

The mud eel, Monopterus cuchia [1] is a freshwater air breathing, swamp mud eel is locally known as cuchia. It commonly occurs in the freshwater of Bangladesh, Pakistan, India, Myanmar and Nepal [2]. Once, indigenous M. cuchia was abundant throughout the Bangladesh, plenty in mud holes in shallow "beels" and 'boro' paddy field particularly in old Sylhet, Mymensingh and Tangail Districts [3]. But presently this fish is hardly found in the open water system. The IUCN, Bangladesh [4] enlisted $M$. cuchia as vulnerable species in the country. But bad water management policy for irrigation, over exploitation and 


\section{International Journal of Oceanography \& Aquaculture}

various ecological changes in its natural habitat; this species is threatened now. [5,6]. Considering the importance of this species in nutritional, economic and biodiversity point of view, its conservation and propagation are considered through fisheries regulation. Studies on the reproductive biology of any fish is essential for evaluating the commercial potentialities of its stock, life history, cultural practice and actual management of indigenous fishes [7,8]. Reproductive potential of a population is one of the basic exigencies to designate the individuals of that population in respect to their gonadal conditions [9]. Knowledge of gonad development and the spawning season of a species allow subsequent studies on spawning frequency of its population, which is very important for its management

Histological study helps in detecting the breeding season and establishing phenotype characters of fully mature breeders for successful propagation of $M$. cuchia. Very little has been done in such direction. Limited literature exists in the sub-continent of India. Some of the earlier works described the process of gonadogenesis and gametogenesis for the Ctenopharyngodon idella [10] and Hypophthalmichthys molitrix [11]. Amblypharyngodon mola [12] and Clupea pallasii [13]. The present work was undertaken to find out the natural reproductive cycle of both sexes of $M$. cuchia based on gonadosomatic index and histological sections. It is very important to assess the breeding cycle of $M$. cuchia to make success in breeding practice. The habitat of water body would be developed and restricted to catch cuchia in the spawning period. As a result, the production of this fish would be increased.

\section{Materials and Methods}

The study was carried out in the ditches of Fish seed multiplication farm, Nerokona between October 2015 and September 2016. The area of each pond was 0.003 ha. The ponds were rectangular and average depth was $1.06 \mathrm{~m}$. The fishes were fed daily with live small fish $(60 \%)$, earthworm (10\%) and dry fish (30\%) at the rate of $2 \%$ body weight.

\section{Sample Collection and Preservation}

The fishes were collected from the grow-out ditches at 15 days interval throughout the study period. Sample fishes were collected with traps. At least 06 fishes were captured for sampling. One hundred and forty four live specimen of M. cuchia at the ages of two years and 250.28 to $480.50 \mathrm{~g}$ in total weight were sacrificed to assess the process of gonadal sex differentiation. A piece of tissue (4 to $5 \mathrm{~mm}$ ) from the gonadal region of the sample was excised with a sharp knife by anatomically and preserved in Boun's solution for histological study. Anatomical differentiation was interpreted as described by Persov [14], while histological concerned the process of gonadal germ cell transformation into either recognizable spermatocytes or oocytes marking the initiation of the first meiosis [15]. The normal expected sex ratio of $M$. cuchia population was determined from data of the gonadal sex differentiation study; confirmed histological sex differences were manifested. Chi-square test was performed to find out the sex ratio of $M$. cuchia population. The accumulated total number of male and female fish was used to calculate the expected ratio of sexes.

\section{Methods for determining the reproductive periodicity of Monopterus cuchia}

a) General Morphology of Gonad: General feature and structure as well as size, shape and colour of male and female gonad was considered of the experimental fish after sample collection and preservation.

b) Gonadosomatic Index (GSI): GSI is frequently applied to determine the spawning frequency of fishes and calculated according to the formula (Lagler 1956): GSI $=($ gonad weight $/$ total weight $) \times 100$.

c) Oocyte Diameter: A small representative part from anterior, posterior and middle portion of the sample was removed separately. The ova was separated in a physiological saline solution $(0.85 \% \mathrm{NaCl})$ and spread on a glass slide to measure the diameter of ova under a microscope with an ocular micrometer. The units of the ocular micrometer standardized with a stage micrometer for measurement of ova diameter in micrometer $(\mu \mathrm{m})$.

d) Histology: The preserved gonads were taken out in a perforated plastic holder, which was covered by perforated steel plates. Cleaning, infiltration and dehydration process was carried out in an automatic tissue processor using a series of alcohol of increasing concentrations, two changes of xylene and finally molted wax ( 3 series). Gonads of male and female fish were studied histologically to find out the different maturational stages of spermatogenesis and oogenesis and their morphology [16]. Gonadal sections were examined and developmental variations were observed. Paraffin embedded blocks was cut by microtome knife at 4-5 micrometers and leaving the sections to a water bath at a temperature of $40^{\circ} \mathrm{C}$. The sections were placed on a glass slide and kept overnight on a slide drier hot plate at a temperature of $20^{\circ} \mathrm{C}$. Then the sections were stained routinely with haematoxyline and eosin [17]. 


\section{International Journal of Oceanography \& Aquaculture}

e) Microscopic Examination: The prepared section was studied under a compound microscope (SWIFT M 4000-D) and photographic records were collected to find out the result of the study.

\section{Results}

\section{Gonadosomatic Index}

Seasonal changes in mean GSI values of both male and female of $M$. cuchia is presented in figure. 1. The mean GSI of cuchia tends to increase as the fish reach maturity and decrease after spawning, it declines and the minimum GSI was recorded during resting phase. In male, the weight of the gonad gradually increased from December to May. It increased stage by stage slowly and reached to a maximum value in May. Highest GSI value $(2.52 \pm 0.44)$ was recorded in May and the GSI values began to fall gently from June to November. In female, the weight of the gonad gradually increased from December to May. It increased stage by stage and reached to a maximum value in May. Highest GSI value $(9.04 \pm 1.02)$ was recorded in May and the GSI values began to fall gently from June to November. The GSI values ranged from $0.70 \pm 0.01$ to $2.52 \pm 0.44$ for male and from $1.09 \pm 0.02$ to $9.04 \pm 1.02$ for female presented in the Figure 1.

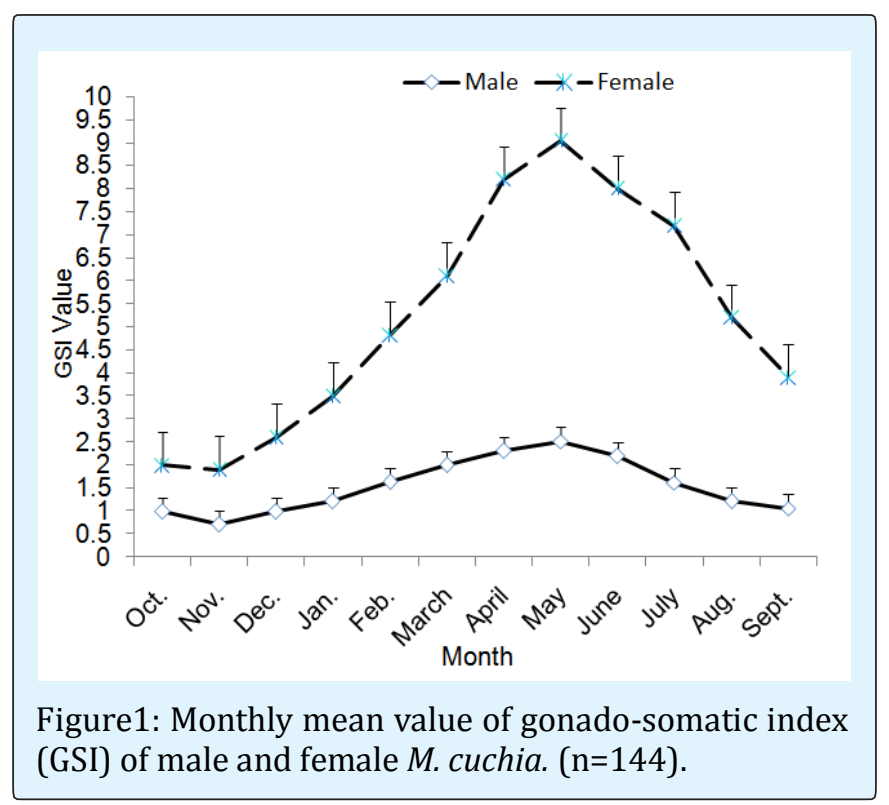

\section{Sexual Differentiation}

The fish was identified by the study of some important morphometric characteristics. It was difficult to identify male and female fish but some external characteristic were helpful to observe sexual differentiation during breeding season. The abdomen of female fish was swollen and pink to brownish in colour with rough abdominal skin (Figure 2A). The abdomen of male fish was sticky and brownish in colour with smooth abdominal skin. Anus and genital pore was observed as tubular in female and round shape in male (Figure. 2B).
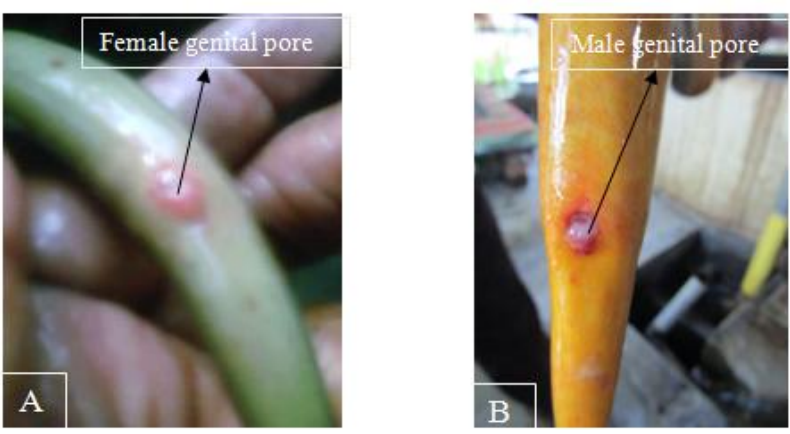

Figures 2 (A-B): Genital pore of Male and Female.

\section{Male Reproductive Cycle}

The first apparent signs of anatomical differentiation were seen in the specimens. The testis is soft and elongated structures lying in the body cavity and ventral to the swim bladder. It leads posterio- ventrally into vas deferen that united to form a spermatic duct opening to the exterior through the urogenital aperture. Testis attached to the dorsal body wall by the connective tissue, mesorchium and composed of numerous thin walled seminiferous lobules. Within the lobule, cells in various stages of spermatogenesis were appeared in discrete nests of cells and each nest consisting of equally Table 1 . Developed cells. Again, the lobule containing more advanced germ cells lied towards the centre of the testis.

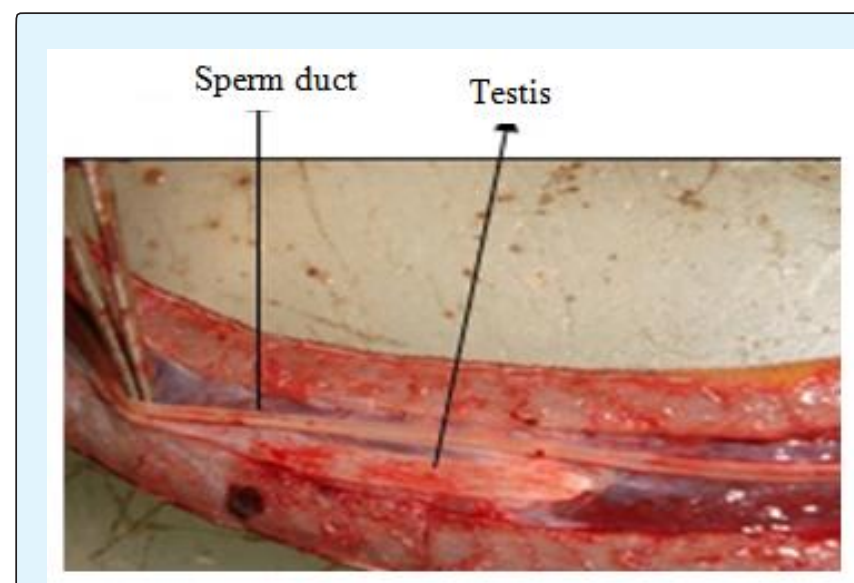

Figure 3: Male gonad (Testis) of M. cuchia. 


\section{International Journal of Oceanography \& Aquaculture}

\begin{tabular}{|c|c|c|c|c|}
\hline \multirow{2}{*}{ Stage of maturity } & \multicolumn{4}{|c|}{ Testes Characteristics } \\
\cline { 2 - 5 } & Length group (cm) & Texture & Color & Histological examination \\
\hline $\begin{array}{c}\text { Premature stage } \\
\text { (Stage I) }\end{array}$ & $10.5-11.5$ & Turgid & White & $\begin{array}{c}\text { Tubule diameter short, compactly packet, } \\
\text { mostly with spermatogonia, wall of tubule } \\
\text { thick. }\end{array}$ \\
\hline $\begin{array}{c}\text { Early maturing } \\
\text { (Stage II) }\end{array}$ & $11.6-12.4$ & $\begin{array}{c}\text { Turgid and folded } \\
\text { structure }\end{array}$ & $\begin{array}{c}\text { Opaque and } \\
\text { creamy } \\
\text { whitish }\end{array}$ & $\begin{array}{c}\text { Tubule diameter large, spermatocytes and } \\
\text { spermatids are dominant, spermatogonia } \\
\text { near the germinal epithelium only; wall of } \\
\text { tubule thin. }\end{array}$ \\
\hline Mature(Stage III) & $12.5-14.2$ & $\begin{array}{c}\text { Turgid, folded and } \\
\text { tight structure }\end{array}$ & $\begin{array}{c}\text { creamy } \\
\text { whitish }\end{array}$ & $\begin{array}{c}\text { Tubule diameter very large filled with } \\
\text { spermatids and spermatozoa. }\end{array}$ \\
\hline Spent (Stage 1V) & $10.5-12.8$ & Loose & Dull white & $\begin{array}{l}\text { Lumen of tubules irregular, a gap between } \\
\text { germinal epithelium and germ cells which } \\
\text { are few and include residual spermatozoa. }\end{array}$ \\
\hline
\end{tabular}

Table 1: Testis characteristics of Monopterus cuchia at various stages of maturity.

The testis varied in length from 10.5 to $14.2 \mathrm{~cm}$ (Figure $3)$. The testis was found in different colour in the development of different stages. At the mature stage, the testis was opaque and creamy white in colour. It was cylindrical and folded structure but not branched. Testis of maturing and mature individual had a turgid texture and folded structure. But the spent individual had a loose texture. Based on size, colour, texture and histological differentiations, four stages of testis were recognized as depicted in Table 1.

\section{Observation}

Testis of $M$. cuchia is made up of a large number of seminiferous tubules of varying size held together by connective tissue. A transverse section of a tubule clearly shows the lumen bounded by a germinative zone and the germ cells in various stages of development. About four distinct stages of spermatogenesis were distinguishable in the male gonad of the experimental fish based on the histology of the nuclear and cytoplasmic morphologies (Table 2 and Figures. 3a-3F), which are described as follows:

\section{Spermatogonia}

Spermatogonia were the first group of the cells to appear during the process of spermatogenesis and hence were most populous near the germinative zone of maturing or mature testis. This is spherical and basophilic structure with a network of chromatin material and nucleoli but distinct nuclear wall. The average diameter was $18.4 \mu \mathrm{m}$. However under light microscopy no distinction could be made between primary and secondary spermatogonia. These cells undergo further mitotic divisions to form primary spermatocyte. The germ cell multiplication becomes more apparent in the testis of fish in the month of December to mid February Figure $4(\mathrm{~A})$.

\begin{tabular}{|c|c|c|c|c|c|c|c|}
\hline Germ cells & Shape & $\operatorname{Size}(\mu \mathrm{m})$ & Cell boundary & Cytoplasm & Nucleus & Nucleoli & Chromosomes \\
\hline Spermatogonia & Spherical & 11.2 & Distinct & Clear & $\begin{array}{c}\text { Nuclear envelope } \\
\text { indistinct }\end{array}$ & Distinct & Forming a network \\
\hline Spermatocytes & Spherical & 8.4 & Distinct & Clear & $\begin{array}{c}\text { Nuclear envelope } \\
\text { indistinct }\end{array}$ & Distinct & Indistinct \\
\hline Spermatids & Spherical & 5.3 & Distinct & Indistinct & Distinct & Invisible & Condensed \\
\hline Spermatozoa & $\begin{array}{c}\text { Crescent with } \\
\text { short tail }\end{array}$ & $\begin{array}{c}\text { L-6.0 } \\
W-1.8\end{array}$ & Indistinct & Indistinct & Indistinct & Indistinct & Indistinct \\
\hline
\end{tabular}

Table 2: General organization of germ cells at light microscope level in testes of Monopterus cuchia.

\section{Spermatocytes}

Spermatogonia run through first maturation division to give rise to secondary spermatocytes. The primary and secondary spermatocytes showed no any marked difference in size. The average diameter of primary and secondary spermatocytes was $8.4 \mu \mathrm{m}$. The secondary spermatocytes, was followed by the second maturation 
division, gave rise to spermatid. Spermatocyte was also spherical in shape containing a nucleus in the centre. The germ cell multiplication became more apparent in the testis in the month of last January and March (Figure 4B \& $4 C)$.

\section{Spermatids}

The spermatids were small rounded bodies $5.3 \mu \mathrm{m}$ in diameter. They have a little cytoplasm and most of their volume is occupied by a large nucleus. The nuclei showed uniform condensed chromatin material. During the development of this stage, the testis of most fish was contained substantial number of germ cells. Following active mitosis, it appeared that the spermatogonia underwent a resting stage before undergoing further meiosis and transformation into primary spermatocytes. The testis was dominated by spermatids in the month of April (Figure 4D).

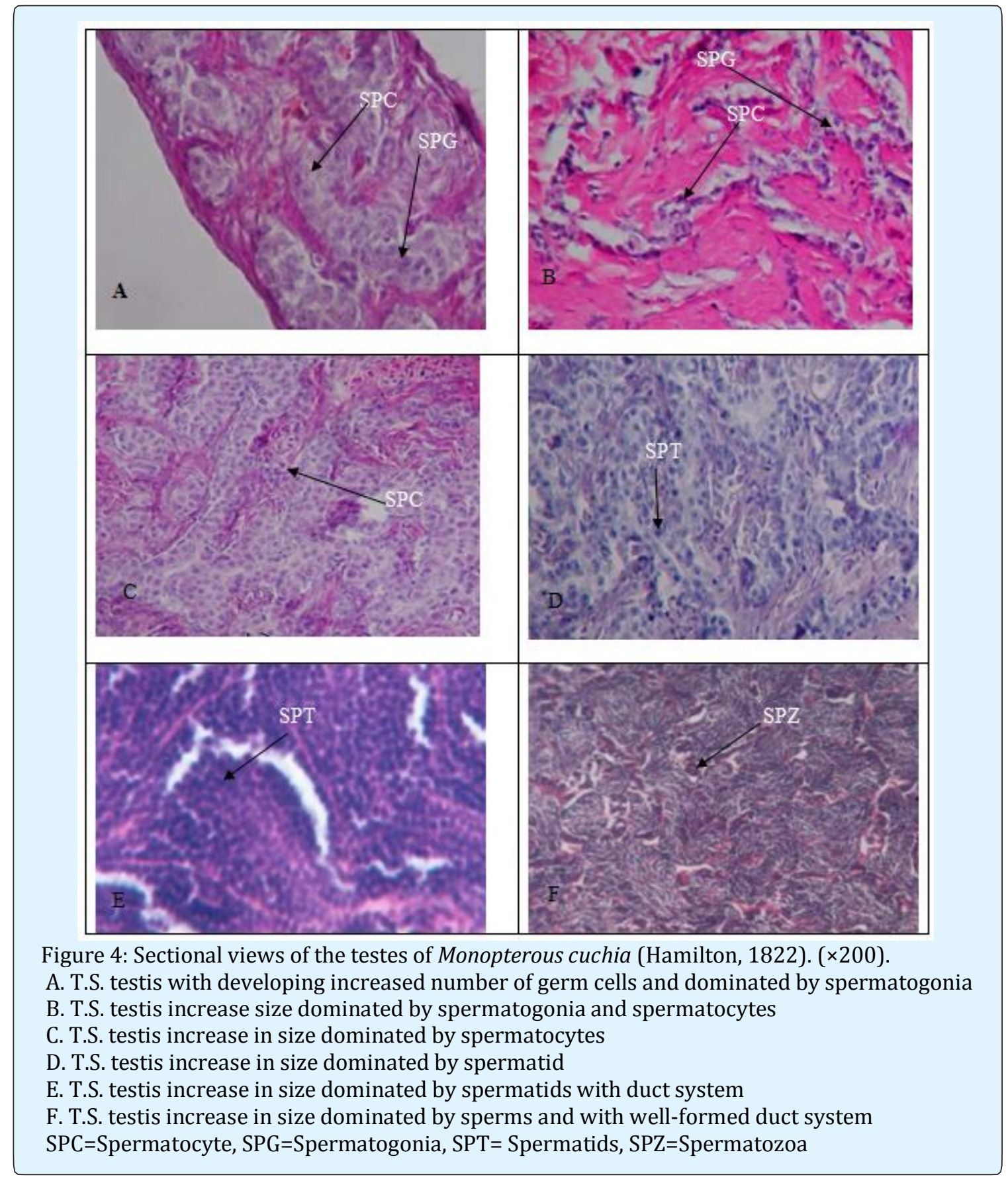

Chakraborty BK. Reproductive Cycle of the Mud Eel, Monopterus Cuchia 


\section{Spermatozoa}

Finally, the spermatids run through certain morphological changes to generate spermatozoa. The spermatozoa were crescent shape structure bearing a short tail. The length of the two end of the crescent measured $6.0 \mu \mathrm{m}$, and widest part in the middle measured $1.8 \mu \mathrm{m}$. This stage was spermatozoa started to develop and prominent in May to June (Figures 4E \& 4F). It became visible as small black-coloured spots under stage were continued up to August. At that time, germ cell development became unchanged. At this stage, the testis had markedly increased in size and similar in appearance on larger fish.

A histological section of testis of the experimental fish was contained highly distinct cysts at all stages of development throughout the period of observation. The percentage of individuals in different stages of maturity observed during different months computed and depicted in Figure 5. In spent testis the germ cell had left the germinal wall of the tubules. The germ cells which included residual spermatids and spermatozoa were scarcely distributed inside the tubules.

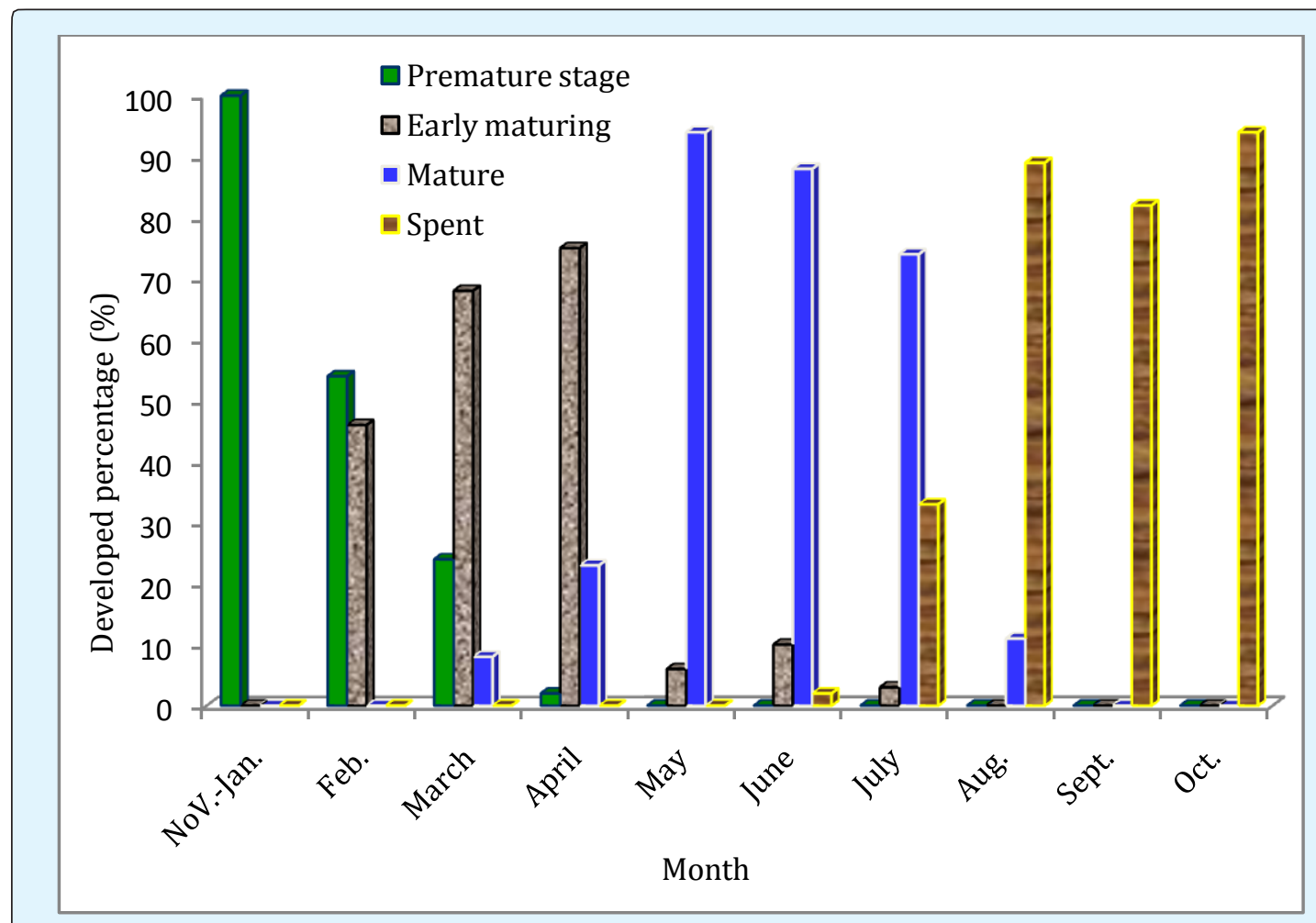

Figure 5: Percentage occurrence of different maturity stages of male Monopterus cuchia.

In March, $24 \%$ and $68 \%$ of the individual had premature and early maturing testes and the rest were on the way to maturity. In April, most of the individuals had early mature and maturing testes. Only $2 \%$ had immature testes. May showed a marked increase in the percentage of maturing fishes (94\%). Some early mature fishes were also found. From May to October, no immature fishes were observed. In June, most remarkable increasing percentage $(88 \%)$ of maturity was recorded and early maturing was recorded $10 \%$, the rest had spent fishes. In July, about $74 \%$ of maturity and $3 \%$ of early maturing was recorded, others were spent fishes. In August, the percentages of mature and spent fishes were $11 \%$ and
89\%, respectively. In September and October all the fishes were spent. But November to January was premature stage. February was equally shared by premature and early maturing fishes.

\section{Female Reproductive Cycle}

There are two lobes in carp species. But M. cuchia has contained only single love. The lobe of the ovary is connected along their dorsal surfaces by a thin mesentery from which they are suspended in the abdominal cavity. Lobe is elongated and found to be cylindrical size Figure $6 \mathrm{~A})$. The anterior parts of the ovary are more or less cylindrical. 


\section{International Journal of Oceanography \& Aquaculture}

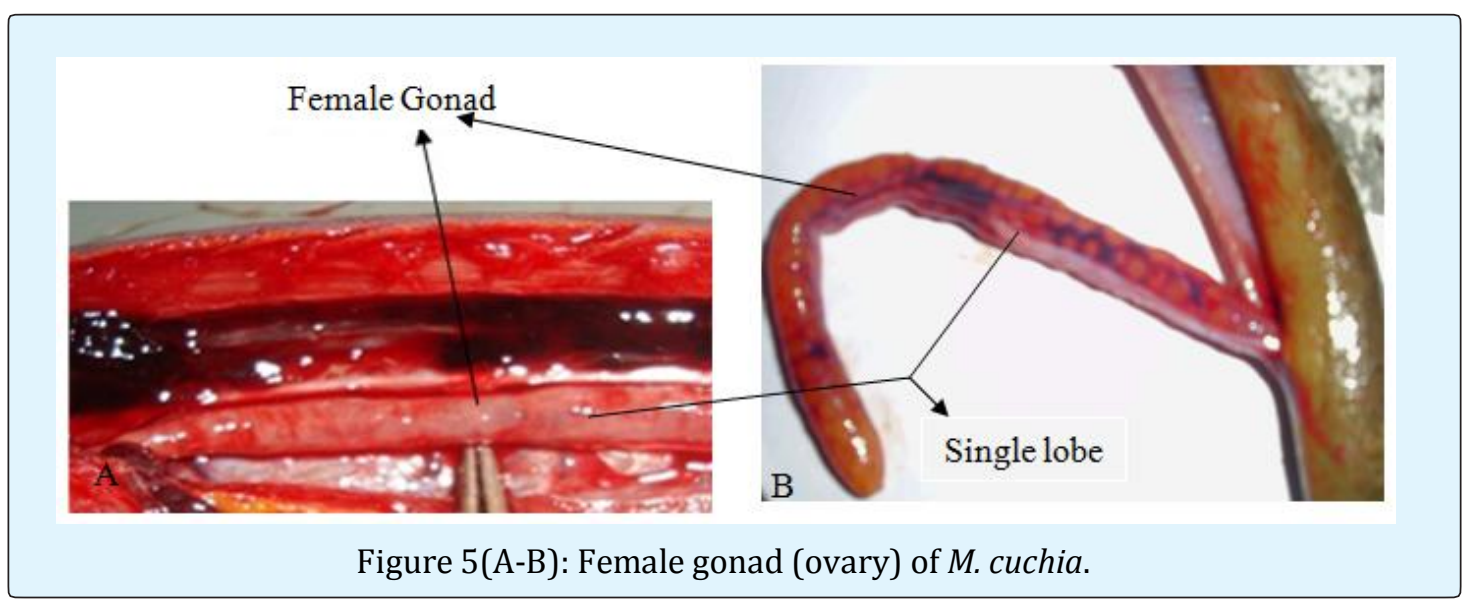

A mesenteries (mesovaria) suspended gonad dorsolaterally to the body cavity. This organ consisted of one ovarian love. It was covered with an ovarian membrane and numerous ovarian lamellae, protected into ovarian cavity. The ovarian cavity connected the oviduct and the oviduct from each bilateral ovary joined to lead to the genital pore. The ovarian lamellae consisted of connective tissue lined by germinal epithelium, which contained cell nests of oogonia. Ovarian follicle developed along the lamellae and the vitellogenic oocytes were ovulated into the ovarian cavity. The follicles of vitellogenic and fully mature oocytes consist of an ovary. The middle portion of the ovarian lobe became broader than both the anterior and posterior region. During breeding season, especially in Mid April to early June, the ovary became very expanded and occupied by the whole cavity. The ovary varied in length from 11.1 to $15.9 \mathrm{~cm}$ and the colour of the developing and maturing ovary of $M$. cuchia was creamy, brownish and yellowish, respectively (Figure 6B). Ovary of maturing and mature individuals had a turgid texture and folded structure, whereas those of spent individuals had a loose texture (Table 3).

\begin{tabular}{|c|c|c|c|c|c|}
\hline \multirow[b]{2}{*}{ Stage of maturity } & \multicolumn{5}{|c|}{ Overy characteristics } \\
\hline & $\begin{array}{l}\text { Length group } \\
\text { (cm) }\end{array}$ & $\operatorname{Size}(\mu \mathrm{m})$ & Texture & Color & Histological examination \\
\hline Privitellogenesis & $12.2-14.8$ & 10.5 & $\begin{array}{l}\text { Turgid and folded } \\
\text { structure }\end{array}$ & $\begin{array}{c}\text { Opaque and } \\
\text { creamy white } \\
\text { brownish }\end{array}$ & $\begin{array}{c}\text { Tubule densely pack, mostly with } \\
\text { oogonia; wall of tubule thick. Nucleus } \\
\text { increased in size with a large number } \\
\text { of nucleoli. Basophilic cells with a } \\
\text { dense and homogenous cytoplasm. } \\
\text { Follicular cells increased around the } \\
\text { oocyte. Zona-radiata was visible. }\end{array}$ \\
\hline Vitellogenesis & $14.9-15.9$ & 11.2 & $\begin{array}{l}\text { Turgid and folded } \\
\text { structure }\end{array}$ & $\begin{array}{c}\text { Creamy } \\
\text { yellowish }\end{array}$ & $\begin{array}{c}\text { Ovary expanded and occupied by the } \\
\text { whole cavity. Oocyte was compact full } \\
\text { with yolk granules. Nucleus was small } \\
\text { in size with nucleoli. Oocyte } \\
\text { surrounded by the clearly } \\
\text { distinguished zona-radiata. }\end{array}$ \\
\hline Atretic stage & $15.9-11.1$ & 10.2 & Loose & $\begin{array}{l}\text { Dull brown } \\
\text { creamy }\end{array}$ & $\begin{array}{l}\text { Lumen of tubules irregular. Atretic } \\
\text { oocytes were due to the reabsorption } \\
\text { of non-vitellogenic and partial } \\
\text { vitellogenic oocytes and the mature } \\
\text { oocyte atresia was due to the } \\
\text { reabsorption of mature oocytes. }\end{array}$ \\
\hline
\end{tabular}

Table 3: Ovaries characteristics of Monopterus cuchia at various stages of maturity. 


\section{International Journal of Oceanography \& Aquaculture}

\section{Maturational Stages of Oocyte}

From the histological point of view, oocytes did not develop synchronously and various maturational stages of oocyte were observed in ovary. The following maturational stages of oocytes of $M$. cuchia were distinguished on the size, appearance of nucleus and nucleolus, and the type of oocytes.

\section{Oogenesis}

The ovary has an outermost epithelial layer. The germinal zone is in the ventrolateral region of the ovary. The oogonial cells are in clusters near the germinal zone which increases in number through repeated mitotic divisions. The mitotic division follows then primary oocytes and finally ova. The developing ova are in radially disposed strings with the immature one towards the germinal zone and the mature one towards the periphery.

The distinction of different stages of oocytes was identified based on the size, their staining affinity, changes in nucleus and the presence and absence of the yolk globules. A brief description of the different stages of oogenesis follows:

Oogonia (OG): In this stage, gonadal attachment to dorsal peritoneum (DP) with oogonia in nests and basophilic oocytes (Oo) were developed. Oogonia were small round cells characterized by a single prominent nucleolus. In the immature ovary, oogonal cells were highly aggregated near the germinal zone. Some residual oogonia were also present in the mature ovary. Oogonia developed into previtellogenic oocytes. They appeared to develop as solitary cells. This stage was observed throughout the year except in the month of May and June (Figure 7A).

Previtellogenic Oocytes: Based on the size, previtellogenic oocytes were further divided into two groups:

Early perinucleolus stage (EPN): Concomitant with oocyte growth, the nucleus increased in size and multiple nucleoli became located around the periphery of the nucleus. This is the stage of basophilic cells with a dense and homogenous cytoplasm. The follicular layer was not visible in this stage (Figure 7A). Early perinucleolus was observed throughout the year but highest number was observed in the month of January (Figure. 7B).

Late perinucleolus stage (LPN): The late perinucleolus stage was distinguished from the early perinucleolus stage by an enlargement of oocyte. Cytoplasm was homogenous and basophilic. Nucleus with a large number of nucleoli was clearly visible. The follicular cells started to develop in this stage around the oocyte, closely connected with the oocyte membrane. In this stage many oocyte possed an accumulation of a small juxtanuclear mass termed 'yolk nucleus' (Figure 7C). This stage was observed throughout the year but highest number was observed in the month of January to mid February.

Vitellogenesis: This was the synthetic phase of the oocytes in which yolk synthesis took place. Follicle cells also started appearing. This stage was marked by considerable changes in nucleus, nucleolus and ooplasm, and a brief description of the different stages of vitellogenesis follows:

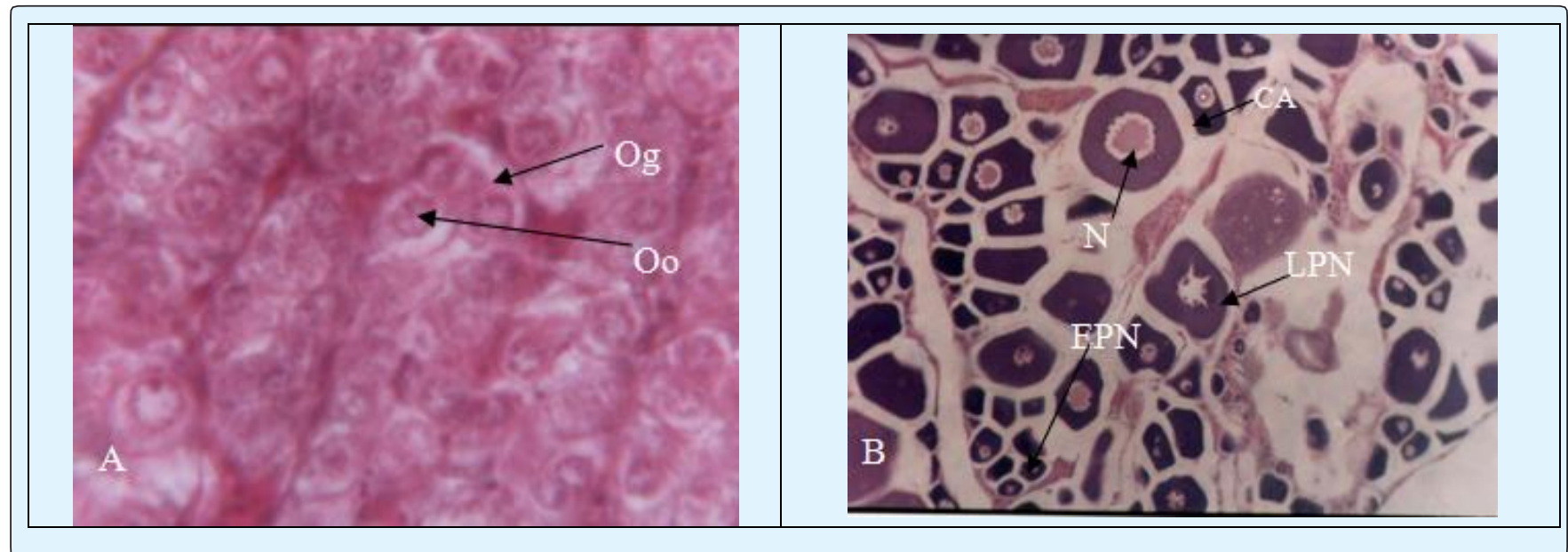

Chakraborty BK. Reproductive Cycle of the Mud Eel, Monopterus Cuchia (Hamilton-Buchanan, 1822) In Bangladesh. Int J Oceanogr Aquac 2018, 2(2): Copyright $@$ Chakraborty BK. 000132. 


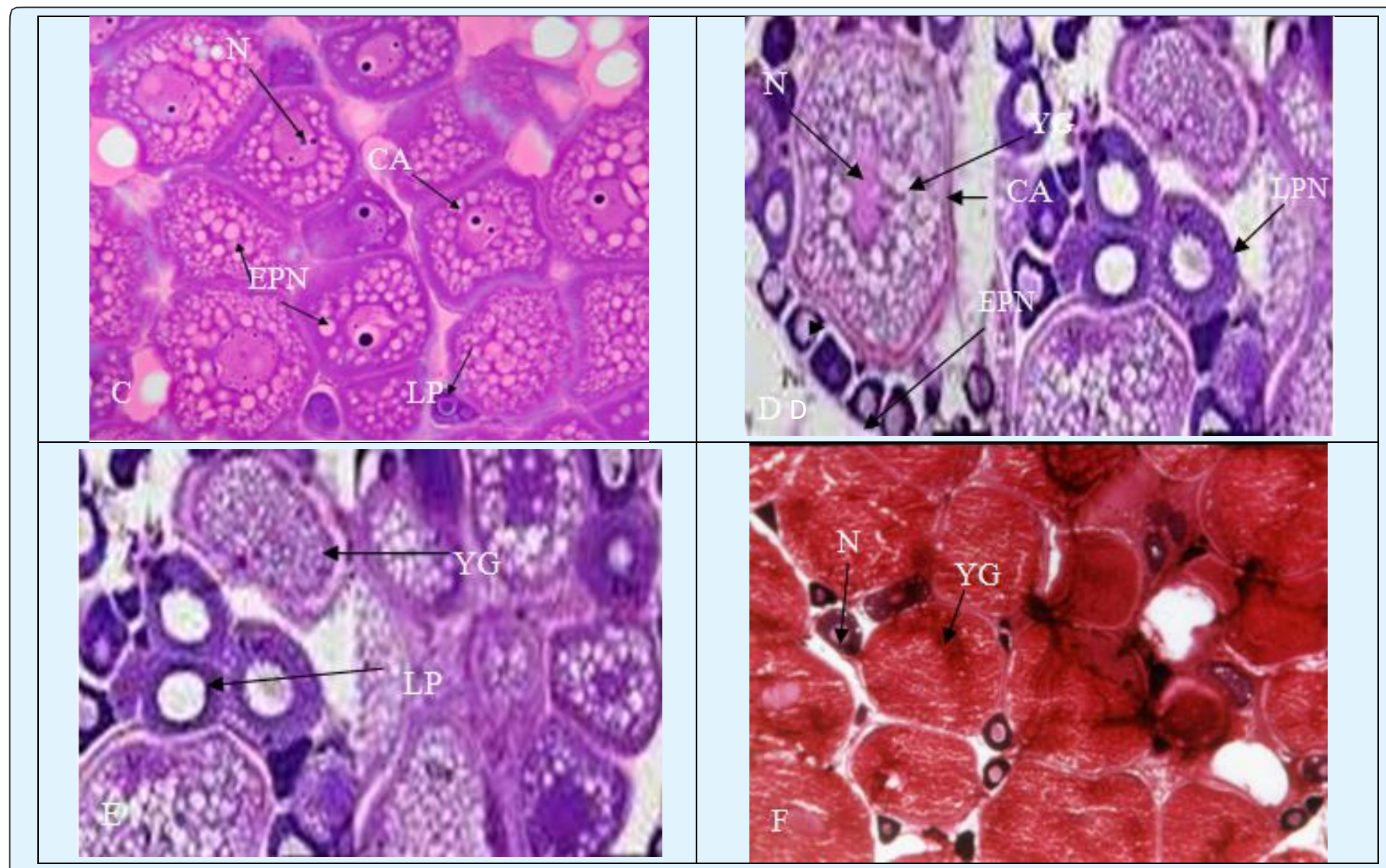

Figure 7: Sectional views of the ovaries of Monopterous cuchia (Hamilton, 1822). ( $\times 200$ ).

A. T.S ovary showing oogenesis at the chromatin and perinucleolus developing stage

B. T.S showing oogenesis at the chromatin; and early EPN and LPN stage

C. T.S ovary with ovigerous lamellae, cytoplasmic oocytes; and EPN and LPN stage

D. T.S ovary increase previtellogenic oocyte and vitellogenic oocyte

E. T.S ovary showing previtellogenic oocyte and vitellogenic oocyte

F. T.S ripe ovary in degenerated stage

$\mathrm{CA}=$ Cortical alveoli, $\mathrm{N}=$ Nucleus, $\mathrm{EPN}=$ Early perinucleolus, $\mathrm{LPN}=$ Late perinucleolus, $\mathrm{YG}=$ Yolk granule.

\section{Early Vitellogenic Oocytes}

This stage was the yolk vesicle stage which is known as cortical alveoli stage (CA). Transparent cortical alveoli appeared in this first stage of the secondary growth phase, situated at the periphery of the oocyte. During this stage the alveoli increased in number leaving only a small zone of basophilic cytoplasm around the nucleus in the larger oocytes (Figure 7D). The zona radiata has become visible. The formation of yolk granules preceded by micropinocytosis of vitellogenin and fusion of the endocytotic vesicles. The nucleus was solid and central in position. Small round follicular cells appeared around oocyte. This stage was observed throughout the year but highest number was observed in April.

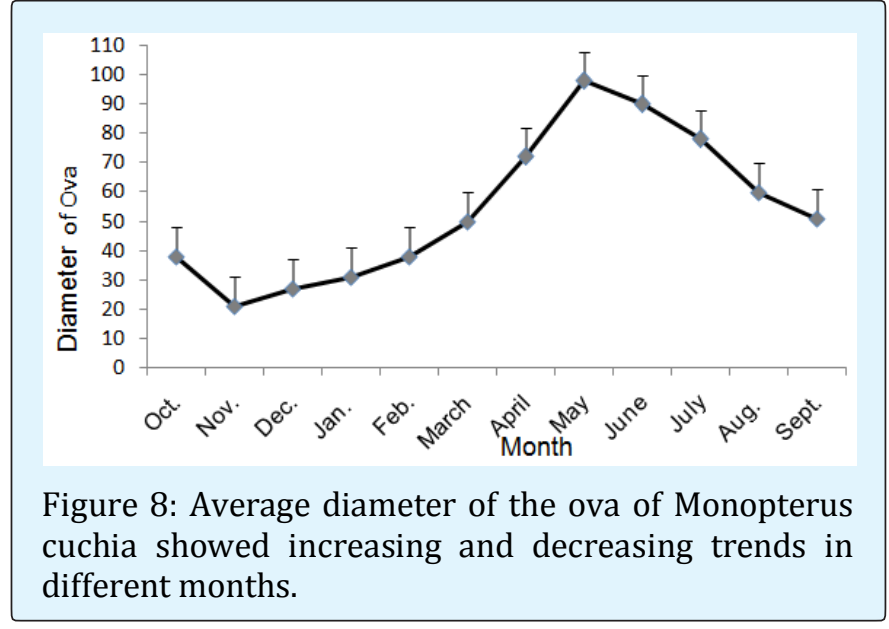




\section{Advanced Vitellogenic Oocytes}

The oocytes further were increased in size and the number of yolk granules was sharply increasing. It was densely packed and occupied almost the total volume of the oocyte. The nuclei of the oocyte located at the centre of oocyte. Cortical alveoli was present both at the periphery of the oocyte and in the perinuclear region. The zona radiata with the radial striation became clearly visible (Figure 7E). The oocyte was surrounded by a thin, but distinguishable granulose layer and a theca layer. The yolk granules developed sharply in May.

\section{Atretic stage (A0)}

Another important structure was observed in the gonad, namely atretic oocyte. The atretic oocytes were classified at three levels: recent atresia, late atresia and mature oocyte atresia. The recent atretic oocytes were due to the reabsorption of non-vitellogenic and partial vitellogenic oocytes and the mature oocyte atresia was due to the reabsorption of mature oocytes (Figure 7F). This type of oocytes was formed after spawning season and it was observed from late July to February.

\section{Development of Ovary}

The primary germ cells (PGC) were apparently undergoing increased mitotic activity proliferating the smaller-sized oogonia, which were arranged in this compact association. Ovary of M. cuchia was developed under normal process of oogenesis at the chromatin and perinucleolus developing stages. The diameter of the ova showed increasing trends from November to May (21.20 \pm 1.02 to $98.50 \pm 1.14 \mu \mathrm{m}$ ) and decreasing trend from June to October $(90.40 \pm 1.14$ to $38.20 \pm 0.08 \mu \mathrm{m})$, respectively (Figure 8).

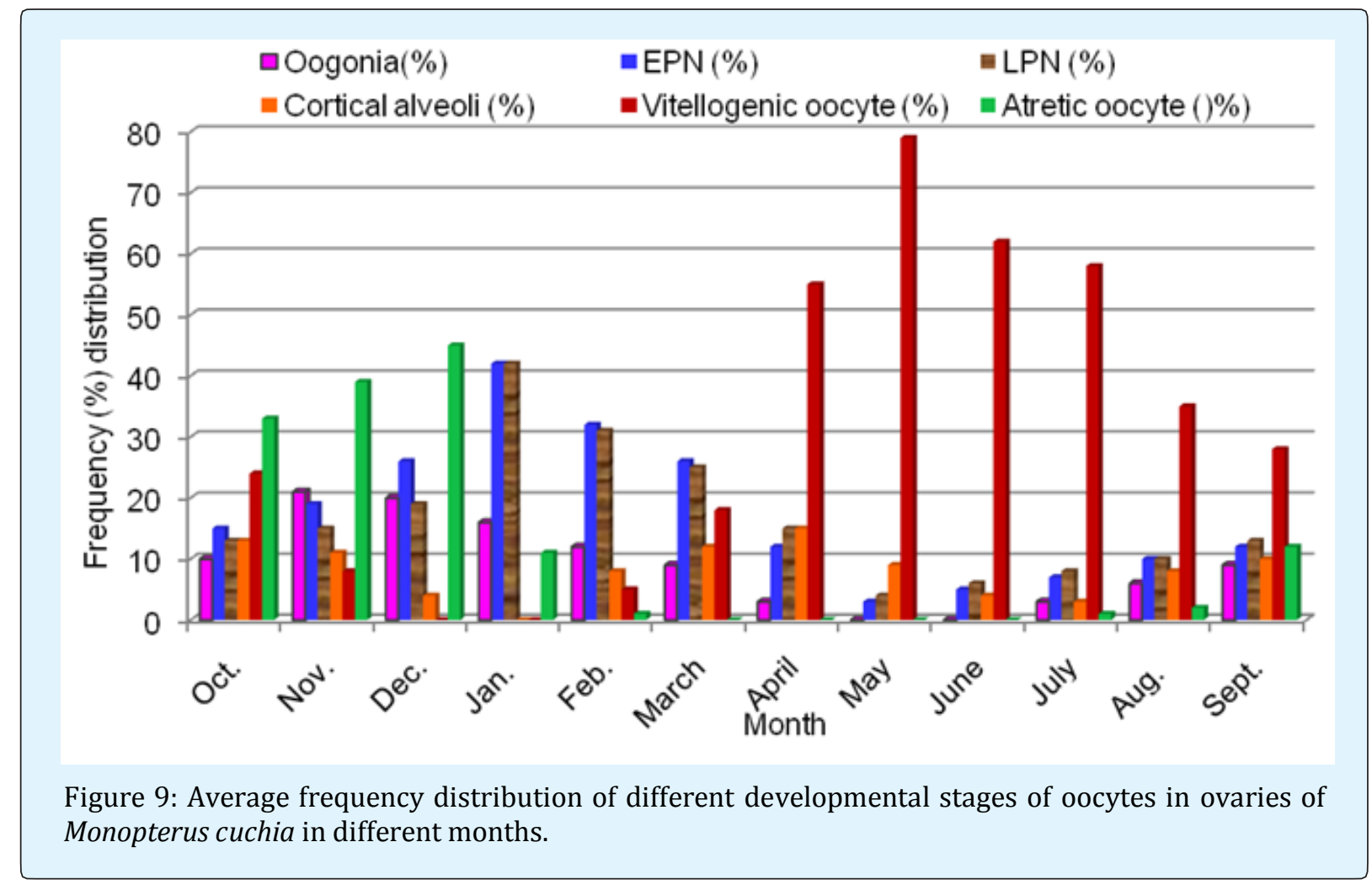

The stages of oogonia and perinucleolar, both early and late, of oocytes were present in different proportions in the ovary throughout the year. The proportion of oogonia, EPN showed a decreasing trends 32 to $0 \%$, an increasing trend from June to December 3 to $30 \%$, decreasing trend from February to May 32 to $0 \%$ and maximum in January (42\%). EPN of oogonia also showed a decreasing trends
41 to $0 \%$, an increasing trend from June to January 3 to $31 \%$, decreasing trend from March to May 22 to $0 \%$ and maximum in February (41\%). The stage of cortical Alveoli occupied in the ovary was varied at the same trend 12 to $3 \%$ from January to June and 5 to $10 \%$ from July to November like oogonia but it was absent in December. The pattern of vitellogenic oocyte distribution showed 


\section{International Journal of Oceanography \& Aquaculture}

increasing trends 0 to $62 \%$ from November to May and decreasing trend 86 to $6 \%$ from July to October but it was absent in November and December. The atretic stage of oocyte is found to occur first in July (1\%) with increase rate in number in the month of December (45\%) but quite absent in March to June. Ovary of the experimental fish contained highly distinct oogonia at all stages of development throughout the period of observation. The percentage of individuals in different stages of maturity observed during different months was computed and depicted in Figure. 9. The maturation of oocytes in $M$. cuchia was found to be asynchronous to partially synchronous because all the oocytes matured at the different time. The developing oocyte percentages indicate that the matured and biggest oocytes are ovulated in the spawning period of last April to June.

\section{Discussion}

Reproductive cycle of indigenous $M$. cuchia was observed the pattern and timing of growth phase and maturation stages of germ cells in the gonad of male and female individual. GSI is usually recognized similarly for male and female. De Vlaming, et al. [18] discussed the utility of GSI as indicator of the reproductive activity of a stock. The GSI increases with the maturation of fish, being maximum during the period of peak maturity and declining abruptly thereafter, when the fish become spent $[19,20]$. The monthly change of GSI reflects the ovarian activity of fish. The results of the present experiment indicated that the GSI of M. cuchia is highest during May when the fish is found to be mature. The increasing GSI of $M$. cuchia suggests that the ovary harbours percentage of yolk laden ripe eggs in May which is more or less similar to Dewan [21] and Chakraborty, et al. [22,23]. They found the spawning period of chela Chela phulo, Puntius sarana and Ompok pabda between June and September.

Reproductive potential of a population is one of the basic exigencies to designate the individuals of that population in respect to their gonadal conditions [9]. In this study, it is observed that testicular development of $M$. cuchia usually occurs earlier than ovarian development. But testicular development of salmononids occurs later than ovarian development Nakamura, et al. [24] and Guraya [25]. The gonad development of M. cuchia was similar in the mud eel, Monopterus albus [26] and similar to another study of monopterus cuchia [27]. The growth of gonad both in male and female was studied. About three stages of oocyte maturation was identified such as: oogenesis (oogonia, early perinucleolus stage and late early perinucleolus stage), vitellogenesis (early vitellogenic oocytes, advanced vitellogenic oocytes and maturation stage) and atretic stage. The stages of oocyte development are similar to that of gold fish [28] and white fish, Caulolatilus princes [29], Puntius gonionotus [30], Puntius sarana and Ompok pabda and somewhat similar to that of Pleuronectes flesus investigated by Jansen et al. [31]. In case of male M. cuchia, four stages of spermatogenesis, such as, spermatogonia (Primary and Secondary), spermatocyte (Primary and Secondary), spermatid and spermatozoa were observed which was very much similar to those found in Barbus luteus [32], Puntius gonionotus [30] common carp, Cyprinus carpio and crucian carp, Carasius cuvieri [33], Puntius sarana [23] and Ompok pabda [1].

The diameter of the ova was significantly higher $(P<0.05)$ in May where it was decreased in November compared to those of different months, which indicates that the diameter of the ova attained highest in the peak spawning season. The ovaries contained oocytes only in early developmental stages up to February are small in size which mostly consists of oogonia, early and late perinucleolus stage, cortical alveoli and yolk granule stage. In the breeding season of $M$. cuchia, the female possessed gonads that contained exclusively vitellogenic oocytes. Similar sequence of oogenesis was also noted in Amblypharyngodon mola and Chela phulo [21] and Puntius sarana [23] and Ompok pabda [1]. A significant percentage of vitellogenesis (55\%) was observed from April onward, climaxing in May. This indicates that ovary maturation is closely correlated with rise in temperature, which is agreed by Khan \& Jhingran [34] in case of female rohu, Labeo rohita. Spawning was observed from May to June as indicated by the presence of an appreciable number of female berried conditions. May to June formed the major spawning period as evidence by the presence of the maximum number of berried and spent fishes in these months. The oocytes in M. cuchia did not mature at the same time. Some of fishes became fully matured; on the other hand, other remained under developing condition. The developing oocyte remained under way of vitellogenesis and gained maturation, and released which supported by the findings of Mustafa [35], and Hora \& Pillay [36] with mola, Amblypharyngodon mola, Ruhu, Labeo rohita and catla, Catla catla.

During study period except in December and February, maturing as well as mature individuals were observed. $M$. cuchia in premature condition were observed maximum in November to January, few in February to April, and altogether absent from May to October. Thus it can be stated that the male breeding period varies from April to 


\section{International Journal of Oceanography \& Aquaculture}

August. In September, all the individuals were found to be spent. It can thus be presumed that the period from September to January is the resting period for male individuals. Temperature is closely correlated to mature testis which is also agreed by Khan \& Jhingran [34] in case of male rohu, L. rohita. M. cuchia normally breeds from late April to early July (Chakraborty 2008, 2010; Chakraborty et al. 2013) [37,38]who reported the breeding season of spiny Guchi, Macrognathus pancalus and M. cuchia is late April to early July with peak in May.

\section{Conclusion}

Finally, it is concluded that identifying spawning period of $M$. cuchia would be very helpful to breeders for breeding of this species. Environmental modification and man-made intervention, spawning grounds of this important fish species have been severely degraded. In this situation, production of seeds through application of this finding might be helpful towards the protection of this species from extinction as well as for its rehabilitation.

\section{Acknowledgement}

The author is gratefully acknowledged the Department of Fisheries, Bangladesh for kind all kind of support and cooperation.

\section{References}

1. Chakraborty BK, Mirza MJA, Chakraborty A (2010) Reproductive cycle of the Endangered Pabda, Ompok pabda (Hamilton-Bouchanan, 1822) in Bangladesh. J Asian Fish Sci Manila Philippines 23 (3): 301-320.

2. Talwar PK, Jhingran AG (1991) Inland fishes of India and adjacent countries. Oxford and IBH Publishing Co PVT Ltd, New Delhi, India, 2: 541.

3. Rahman AKA (1989) Fresh water Fishes in Bangladesh. pp: 263-264.

4. IUCN (2000) List of threatened animal of Bangladesh. Paper presented in the Workshop on Bangladesh Red Book of Threatened Animals, Dhaka, pp: 13.

5. Disaster E (1990) Floodplain protection in Central Europe. World Wildlife Found (WWF) Institute of Floodplains Ecology, Germany.
6. Chakraborty BK, NN Nur (2009) Study on aquatic biodiversity of Medha Beel in the Northern Bangladesh. Journal of Crop and Weed 5(2): 4-11.

7. Lagler KF (1956) Fresh Water Fishery Biology. $2^{\text {nd }}$ (edn), WM Brown Company, Bubuque, Lowa, pp: 541.

8. Doha S, Hye MA (1970) Fecundity of Padma River hilsa, Hilsa ilisha (Ham.). Pakistan J Sci 22(3-4): 176178.

9. Jhingran AG, Verma DN (1972) Sexual maturity and spawning of Gadusia chapra (Ham.) in Ganga river system. Proc Nat Sci Acad India 42(2): 207-224.

10. Jensen GL, Shelton WL (1983) Gonadal differentiation in relation to sex control of grass carp, Ctenopharyngodon idella (Pisces: Cyprinidae). Copeia, 1983: 749-755.

11. Mirza JA (1983) Inducement of sex reversal in silver carp. Ph.D. dissertation, Department of Fisheries and Allied Aquacultures, Auburn University of Alabama, USA, pp: 61.

12. Afroze S, Hossain MA (1990) The reproductive cycle of the freshwater fish Amblypharyngodon mola (Ham.) (Cyprinidae). Univ J Zool Rajshahi University, Rajsh ahi, Bangladesh 9: 17-21.

13. Koya Y, Soyano SK, Yamamoto K, Obana H, Matsubara $\mathrm{T}$ (2002) Testicular development and serum profiles of steroid hormones levels in captive male Pacific herring Clupea pallasii during their first maturational cycle. Fish Sci 68: 1099-1105.

14. Persov G (1972) Functional liability of the reproductive system of fish. J Ichthyol 12: 226-240.

15. Barr WA (1968) Patterns of ovarian activity, In: E.J. Barrington and C.B. Jorgensen (eds), Perspectives in Endocrinology, Hormones in the Lives of Lower Vertebrates. Academic press, London and New York, USA, pp: 163-237.

16. Vitale F, Svedang H, Cardinale M (2006) Histological analysis invalidates macroscopically determined maturity ogives of the Kattegat cod (Gadus morhua) new proxies for estimating maturity status of individual fish. ICES J Mar Sci 63: 485-492.

17. Humason GL (1972) Animal Tissue Techniques. WH Freeman and Co., San Francisco, CA, pp: 614. 


\section{International Journal of Oceanography \& Aquaculture}

18. De Vlaming V, Grossman G, Chapman F (1982) On the use of the gonado-somatic index. Com Biochemis and Physiol 73: 31-39.

19. Le Cren ED (1951) The length-weight relationship and seasonal cycle in gonad weight and condition in perch. J Anim Ecol 20: 201-219.

20. Huang YC, Jeng SS, Chen HM, Hwan DF (2008) Identification of nine species of moray eel by SDSPAGE. The Raffles Bulletin of Zoology 19: 123-129.

21. Dewan S (1973) Investigation into the ecology of fishes of Mymensingh Lake. PhD dissertation. Bangladesh Agril Uni Mymensingh, Bangladesh, pp: 235.

22. Chakraborty BK (2010) Fecundity and Induction of spawning in spiny Guchi, Macrognathus pancalus (Blioch \& Schneider) in Bangladesh. Bangladesh Journal of Zoology 38(1): 77-91.

23. Chakraborty BK, Mirza MJA, Miah MI, Habib MAB, Chakraborty A (2007) Reproductive cycle of the Endangered Sarpunti, Puntius sarana (Hamilton, 1822) in Bangladesh. J Asian Fish Sci Manila, Philippines 20(2): 145-164.

24. Nakamura M, Kobayashi T, Chang XT, Nagahama Y (1998) Gonadal sex differentiation in teleost fish. J Exp Biol 281: 362-372.

25. Guraya SS (1994) Gonadal development and production of gametes in fish. Proc Nat Sci Acad 60: 15-32.

26. Mei W, Cao Y, Li R, Shi B, Hu A (1993) A preliminary observation on sex reversal of the mud eel Monopterus albus. J Zhenjiang Shuichan Xueyuan Xuebao 12: 53-58.

27. Miah FM, Haque F, Mia MR, Jannat E, Ali $\mathrm{H}$, et al. (2013) Molecular identification and sexual differentiation of fresh water mud eel, Monopterus cuchia. Universal Journal of Agriculture Research 1(3): 54-58.

28. Yamamoto K, Onozat H (1965) Electron microscope study on the growing oocyte of the gold fish during the first growth phase. Memo Fac Fish Hakkaido Univ 13(2): 79-106.

29. Elorduy-Garay JF, Ramirez-Luna S (1994) Gonadal development and spawning of female ocean white fish, Caulolatilus princeps in the Bay of La Pazz., B.C.S., Mexico. J Fish Biol 44: 553-566.

30. Afroz Z (1996) Comparative study of the gonadal histology and morphology of three different interspecific hybrids of Puntius gonionotus (Bleeker). M.Sc. Dissertation, Department of Zoology, Dhaka University, Dhaka, Bangladesh, pp: 138.

31. Janseen PAH, Lambert JGD, Goos HJT (1995) The annual ovarian cycle the influence of pollution of vitellogenesis in the flounder, Pleuronected flesus. J Fish Biol 47: 509-523.

32. Bhatti MN, Al-Daham NM (1978) Annual cyclical changes in the testicular activity of a freshwater teleost, Barbus luteus (Heckel), from Shatt-Al Arab, Iraq. J Fish Biol 13: 321-326.

33. Matsumoto T, Kobayashi M, Nihel $\mathrm{Y}$, Kaneko $\mathrm{T}$, Fukada H, et al. (2002) Plasma vitellogenin levels in male common carp Cyprinus carpio and crucian carp Carassius cuvieri of Lake Kasumigaura. Fisheries Science 68: 1055-1066.

34. Khan HA, Jhingran VG (1975) Synopsis of biological data data on rohu, Labeo rohita (Hamilton, 1822) Central Inland Fisheries Research Institute, Barrackpore, West Bengal, India, pp: 20.

35. Mustafa G (1991) Composite culture and biology of some indigenous fishes of Bangladesh. Ph. D. Dissertation. Faculty of Biological Science, Dhaka University, Dhaka, pp: 299.

36. Hora SL, Pillay TVR (1962) Hand Book of Fish Culture in Indo-Pacific Fisheries Region. FAO Fish Biol Tech Pap 14: 203.

37. Chakraborty BK (2008) Induction of spawning in spiny Guchi, Macrognathus pancalus (Blioch \& Schneider) in Bangladesh. In: G.K. Vinci, S.K. Manna, V.R. Suresh, K. Mitrhra, N.V. Shrivasta, K.K. Vas A.P. Sarma (Eds.), The $8^{\text {th }}$ Indian Fisheries Forum Proceedings, published by IFSI, Kolkata and APSIB, Mangalore, India, pp: 186-193.

38. Chakraborty BK, Azad SA, Barmon B, Faruque AMO (2013) Fecandity and gonado Somatic Index of gangetic mud eel, Monopterus cuchia (Hamilton, 1922). Bangladesh Journal of Zoology 41(2): 165-172. 